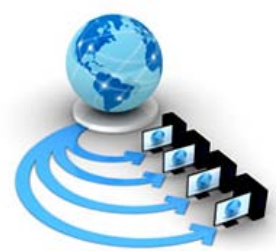

Volume 9, No. 2, March-April 2018

International Journal of Advanced Research in Computer Science

RESEARCH PAPER

\title{
PREVALENCE OF MUSCULOSKELETAL DYSFUNCTION IN COMPUTER SCIENCE STUDENTS AND ANALYSIS OF WORKSTATION CHARACTERISTICS- AN EXPLORATIVE STUDY
}

\author{
Dr. Shweta Nahar (PT) \\ Physiotherapist, MPT Musculoskeletal Sciences, \\ MGM Institute's University Department of Physiotherapy, \\ Kamothe, Navi Mumbai, Maharashtra, India
}

\author{
Dr. Adil Sayed (PT) \\ Physiotherapist, Department of Musculoskeletal Sciences, \\ MGM College of Physiotherapy, \\ Kamothe, Navi Mumbai, Maharashtra, India
}

\begin{abstract}
Background: Ergonomics in a computer is an essential factor nowadays; which requires proper working posture and proper arrangement of workstation accessories which provides great comfort to the individual while working that helps to prevent the musculoskeletal pain and dysfunction. As computer usage is now an integral part of training in the next generation, the available literature indicates that musculoskeletal dysfunction associated with the computer use is prevalent not only in adults but also in college going students. Aim: To find out the musculoskeletal dysfunction in computer science students and to assess the physical workstation characteristics among computer science students. Methods: 100 students were selected from four computer science institutes based on inclusion and exclusion criteria. Cornell Musculoskeletal Dysfunction Questionnaire (CMDQ) was used as an outcome measure for musculoskeletal dysfunction and 40 workstation analyses were done. Workstation analysis consisted of measuring the postural angles and workstation characteristics. Results: Study showed a higher prevalence of neck dysfunction (65\%) followed by low back dysfunction (61\%). $74 \%$ of the students were not aware of the proper ergonomics of the computer workstation. Conclusion: All the institutes had a higher prevalence of musculoskeletal dysfunction in computer science students. Majority of the students were not aware of the proper ergonomics of the computer workstation. Prior establishment of work setup, an appropriate analysis of workstation and its characteristics is needed in all the computer science institutes.
\end{abstract}

Keywords: Musculoskeletal dysfunction, prevalence, computer science students, ergonomics, workstation analysis, workstation characteristics, postural angles

\section{INTRODUCTION}

The International Ergonomics Association (IEA) defines the ergonomics as a study of a workstation concerned with the understanding of interactions among humans and other elements of a system, and the profession that applies theory, principles, data, and methods to design in order to optimize human well-being and system performance. ${ }^{[1]}$ Ergonomics in a computer is an essential factor nowadays; which requires proper working posture, proper arrangement of workstation accessories allowing great comfort to individuals while working and helps to prevent the musculoskeletal pain and dysfunction. ${ }^{[1-3]}$

The prevalence of Musculoskeletal Dysfunctions (MSDs) is higher and is increasing every year globally. ${ }^{[1-2]}$ Studies have reported that individuals diagnosed with MSDs were directly related to poorly designed workstations. ${ }^{[2]}$ MSDs are defined as repeated trauma to the tissues, joints, tendons, and nerves that affect the muscles and supporting structures of the body, caused by the risk factors of work nature or by an employee's working environment. ${ }^{[2,3]}$ Various problems have been associated with the use of a computer. Studies have reported that visual and musculoskeletal discomfort, particularly the neck, shoulder, arms, low back were common in computer workers. ${ }^{[4,5,6]}$ Excessive repetition of a particular task at the workplace for example typing, keying, prolonged duration of work, the amount of force for a task, sustained awkward posture and exposure to combinations to these factors further increases the risk and development of musculoskeletal dysfunction. ${ }^{[5,6]}$
Also if the workstations are poorly designed, it will result in a poor posture as the excessive strains placed on a particular group of muscles, and therefore the discomfort level increases. [1] Hence, it is necessary to analyze the workstation characteristics and to study the ergonomic design associated with the risk factors and the level of MSK dysfunction in computer users.

The critical health factors of computer science professionals consisting of the physical atmosphere including working conditions, health consciousness, knowledge of handling computer peripherals, the importance of health and safety training on ergonomics, job design and healthcare initiatives taken by the topmost management. ${ }^{[7]}$ The other factors contributing to the occurrence of computer related health problems are working environment, the degree of mobilization and level of constrained posture, awareness level and practices of workers regarding computer ergonomics.

The most productive and hardworking students are the most likely to get injured. Thus all the findings of the previous study concluded that the health-related ergonomic knowledge as an important factor for the occurrence of health problems in the Information Technology (IT) students. Moreover, it is found that the research studies focusing on capturing the perception of IT employee's and student's knowledge about the ideal computer workstation arrangements and the optimal posture while working on the computer are much limited in the literature. ${ }^{[8.9]}$ Another point of consideration is the design of computer workstation prevailing in the Indian education system despite the 
existence of various international standards for the ideal workstation.

As computer usage is now an integral part of training in the next generation, the available literature indicates that MSK discomfort associated with computer use is prevalent not only in adults but also in college going students including those in college, ${ }^{[5,8,10]}$ as well as high school grade and grade school. ${ }^{[11.12]}$ Hence the purpose of our study was to find out the prevalence of MSK dysfunction amongst computer science students and to analyze the workstation characteristics.

Our aims and objectives were:

1. To find out the MSK dysfunction in computer science students

2. To find out the most prevalent MSK dysfunction in computer science students

3. To assess the physical workstation characteristics among computer science students

\section{MATERIALS AND METHOD}

Participants: Students pursuing computer science bachelor degree course from first to final year were included in the study. 100 computer science students were selected from four computer science institutes (25 students per each institute) from Navi Mumbai. Students other than computer science field and students having any previous musculoskeletal conditions were excluded from the study. For workstation analysis, 40 workstations were selected from four computer science institutes (10 workstations per each institute) from Navi Mumbai. All the procedures were explained to the students' prior commencement of the study and the information was kept confidential.
Method: A signed informed consent was obtained from all the students. The Cornell Musculoskeletal Dysfunction Questionnaire (CMDQ) ${ }^{[13]}$ was used as an outcome measure to determine the musculoskeletal dysfunction among computer science students. The questionnaire was explained to the students prior and then they filled the questionnaire. Basic demographic details were obtained including the occupational history. The occupational history consisted of the total duration of computer use since years and total hours of computer use in a day; the position adopted for computer use; frequency of adjusting the monitor level, keyboard support, document holder, work surface; presence of micro pauses during the computer work; and awareness of ergonomics. The CMDQ consisted of a human body diagram in which the human body parts have mentioned and students were assigned to put the tick mark for the presence of any musculoskeletal dysfunction in a particular position of body part/parts. The questionnaire also included the components such as; the duration of pain/discomfort, the frequency of pain/discomfort based on their level of comfort and severity of pain/discomfort that had interfered their ability to work. The workstation was analyzed in two components; that is postural angles and workstation layout. Postural angles consisted of viewing angle, elbow angle, hip angle, knee angle and distance between knee and keyboard. Postural angles were measured by the universal goniometer. ${ }^{[14]}$ The workstation layout consisted of screening for chair adjustability, the presence of chair tilt, and presence of forearm support and lumbar/back support of chair along with measurement of desk height, seat height, forearm support height and back support height by measuring tape.

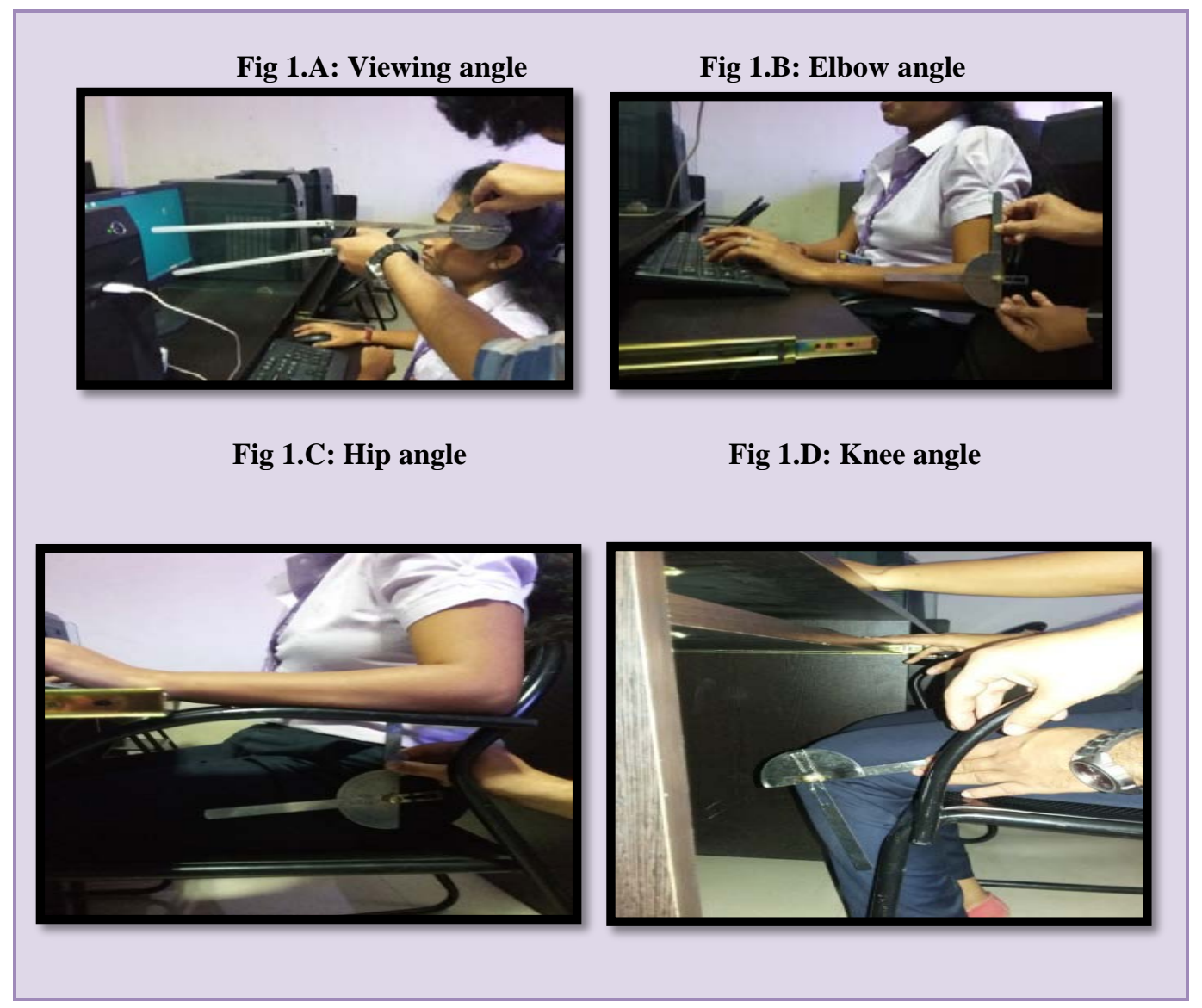

Figure 1: Postural angles 


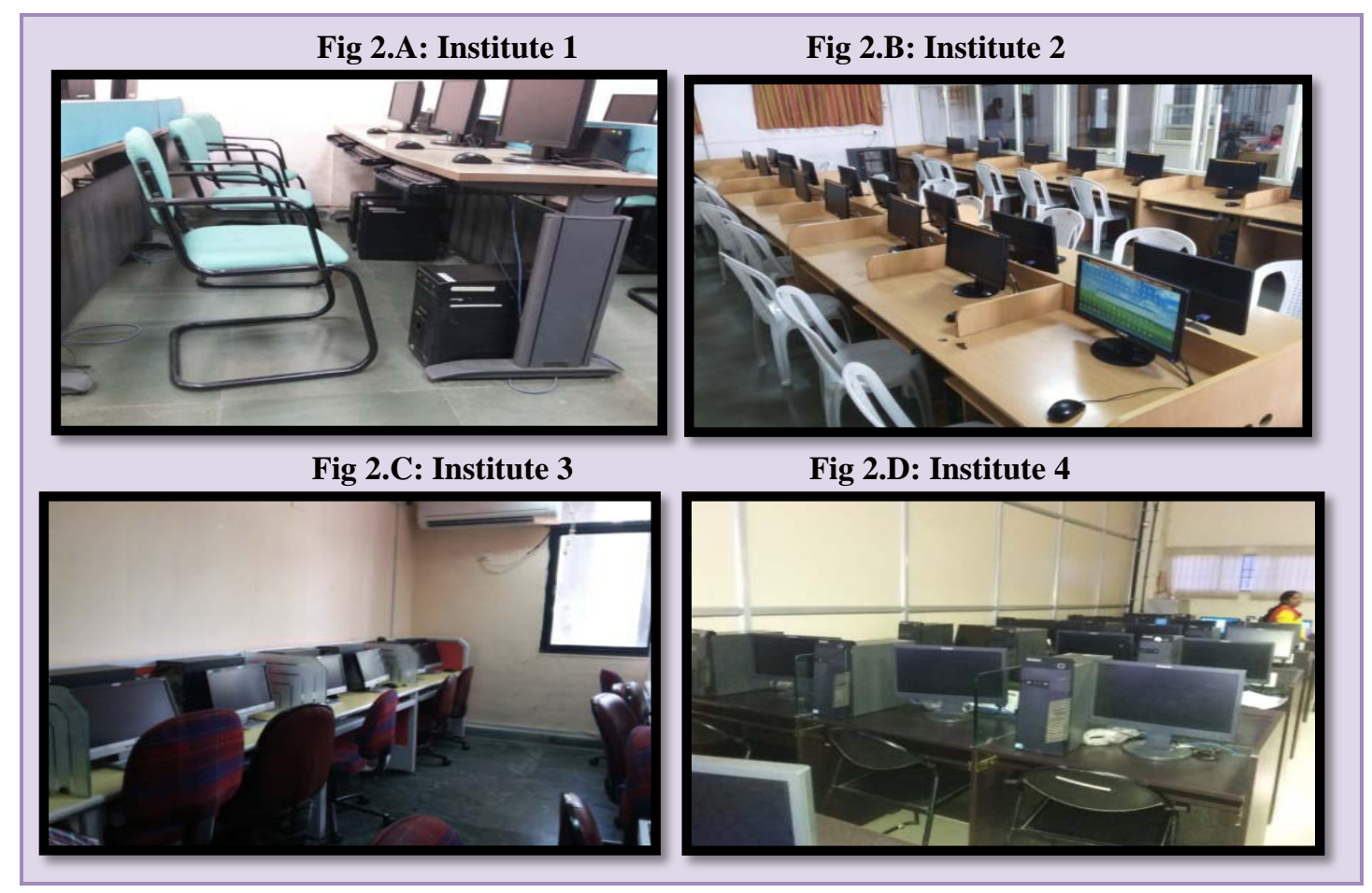

Figure 2: Workstation layout

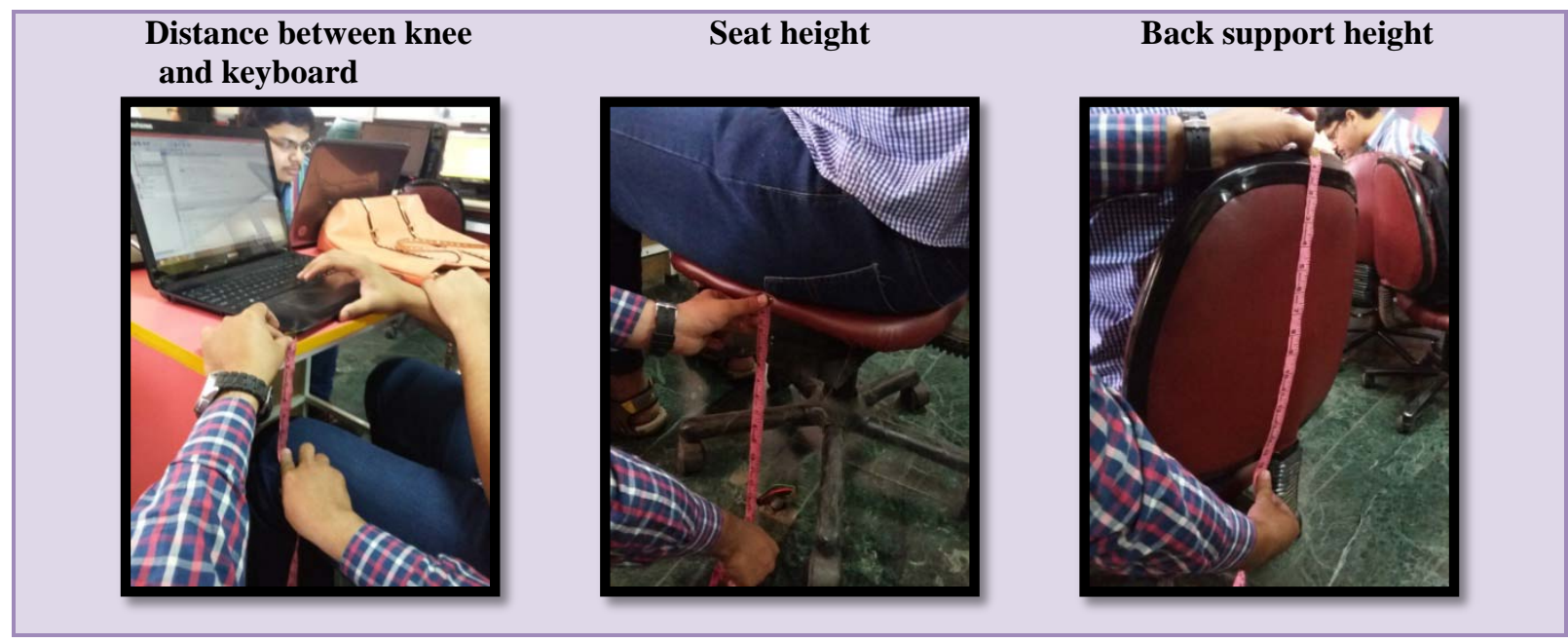

Figure 3: Workstation characteristics

Statistical analysis: Data analysis was done using IBM SPSS software v16. The prevalence of MSK dysfunction was calculated and workstation analysis was done.

\section{RESULT}

In the demographic details, among 100 computer science students; 58\% (58/100) were boys and 42\% (42/100) were girls from the age group of 18 to 25 years. Table 1 has stated the characteristics of computer science students.
Table 1: Demographic data

\begin{tabular}{|l|c|c|}
\hline \multicolumn{1}{|c|}{ CHARACTERISTICS } & MEAN & $\begin{array}{c}\text { STANDARD } \\
\text { DEVIATION }\end{array}$ \\
\hline 1. AGE & 21.12 YEARS & \pm 2.19 \\
\hline 2. HEIGHT & 5.41 METER & \pm 0.46 \\
\hline 3. WEIGHT & $58.63 \mathrm{KG}$ & \pm 12.92 \\
\hline 4. DURATION OF & & \\
COMPUTER USE & 7.19 & \pm 3.65 \\
A] In years & 4.69 & \pm 2.97 \\
B] In hours & & \\
\hline
\end{tabular}


The components of occupation history were described in table 2. Majority of the students (62\%) (62/100) used the laptop at home while 35\% (35/100) had used desktop and $3 \%(3 / 100)$ were used both laptop and desktop at home. $65 \%(65 / 100)$ students stated that their monitor was nonadjustable. 74\% (74/100) of the students were not aware of the ergonomics of the computer workstation.
Table 2: Occupational components of computer workstation

\begin{tabular}{|cl|c|c|}
\hline COMPONENTS & YES & NO \\
\hline 1. & Adjusting monitor level & $35 \%$ & $65 \%$ \\
\hline 2. & $\begin{array}{l}\text { Presence document } \\
\text { holder }\end{array}$ & $62 \%$ & $38 \%$ \\
\hline 3. & $\begin{array}{l}\text { Presence of micro } \\
\text { pauses }\end{array}$ & $84 \%$ & $16 \%$ \\
\hline 4. $\begin{array}{l}\text { Awareness of } \\
\text { ergonomics }\end{array}$ & $26 \%$ & $74 \%$ \\
\hline
\end{tabular}

Table 3.A] and 3.B] have stated the analysis of workstation characteristics including postural angles and workstation layout among 40 workstations.

Table 3.A]: Workstation characteristics

\begin{tabular}{|c|c|c|c|c|c|}
\hline & Institute 1 & Institute 2 & Institute 3 & Institute 4 & Normal Range \\
\hline $\begin{array}{l}\text { A] Postural angles (in degrees) } \\
\text { 1. Viewing angle } \\
\text { 2. Elbow angle } \\
\text { 3. Hip angle } \\
\text { 4. Knee angle }\end{array}$ & $\begin{array}{c}\text { (mean) } \\
21.7 \\
98 \\
94 \\
93\end{array}$ & $\begin{array}{l}\text { (mean) } \\
14.2 \\
81 \\
108.5 \\
79\end{array}$ & $\begin{array}{c}\text { (mean) } \\
19 \\
89 \\
97.5 \\
88.5\end{array}$ & $\begin{array}{c}\text { (mean) } \\
23 \\
108 \\
92.5 \\
83\end{array}$ & $\begin{array}{l}\text { (Degrees) } \\
15-30 \\
90-110 \\
90-110 \\
90-110\end{array}$ \\
\hline $\begin{array}{l}\text { Distance between knees and keyboard } \\
\text { (in centimetres) }\end{array}$ & 6 & 4 & 5 & 6.5 & 8-15 \\
\hline $\begin{array}{l}\text { B] Workstation layout (in inches) } \\
\text { 1. } \\
\text { 2. } \\
\text { 3. } \\
\text { Seat height } \\
\text { 4. } \\
\text { Forearm support height } \\
\text { Foreapport height }\end{array}$ & $\begin{array}{c}30 \\
17 \\
9 \\
26\end{array}$ & $\begin{array}{c}30 \\
17 \\
19 \\
0\end{array}$ & $\begin{array}{c}30 \\
15.5 \\
16 \\
0\end{array}$ & $\begin{array}{l}30 \\
17 \\
10 \\
26\end{array}$ & $\begin{array}{c}25-30 \\
16-20 \\
8-12 \\
25-30\end{array}$ \\
\hline
\end{tabular}

Table 3.B] Workstation characteristics

\begin{tabular}{|cl|c|c|}
\hline \multicolumn{2}{|l|}{ CHARACTERISTICS } & YES & NO \\
\hline 1. & Adjustable chairs & $0 \%$ & $100 \%$ \\
\hline 2. & Presence of chair tilts & $0 \%$ & $100 \%$ \\
\hline 3. & Presence of forearm support & $50 \%$ & $50 \%$ \\
\hline 4. & Presence of back support & $100 \%$ & $0 \%$ \\
\hline
\end{tabular}

All the four institutes had chairs with a back support. But none of them had chair adjustability and presence of chair tilts. Only two institutes had forearm support (50\%) (20/40), and two institutes did not have forearm support (50\%) (20/40).

Graph 1 represents the prevalence of musculoskeletal dysfunction of computer science students of all the four institutes. Neck pain (65\%) was the most prevalent MSK dysfunction among computer science students followed by the low back pain (61\%). 35\% had reported the upper back pain while $30 \%$ had reported shoulder and wrist pain/dysfunction.

Graph 1: Prevalence of Musculoskeletal Dysfunction

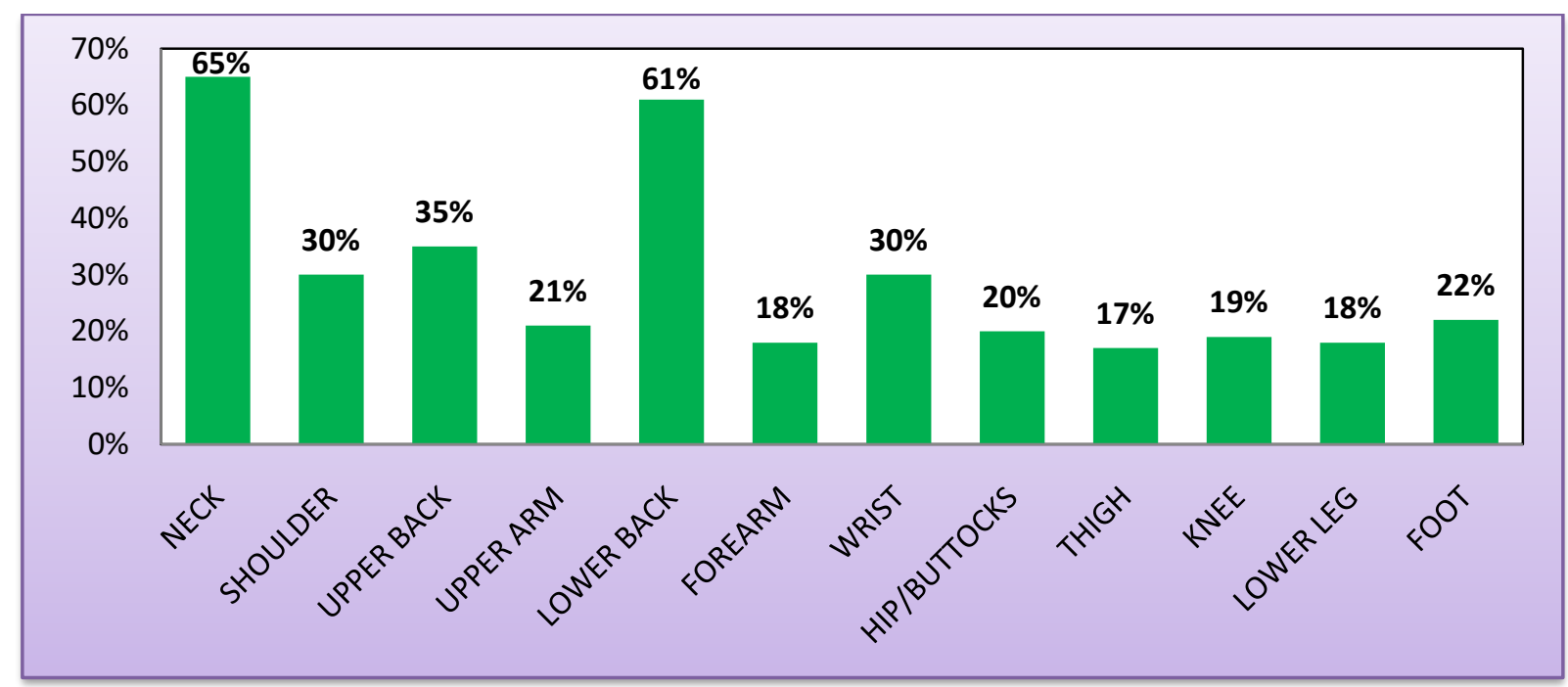


Graph 2 represents the musculoskeletal dysfunction level. $50 \%$ students were slightly uncomfortable due to musculoskeletal dysfunction while $9 \%$ were very uncomfortable due to MSK dysfunction.

\section{Graph 2: Musculoskeletal Dysfunction Level}

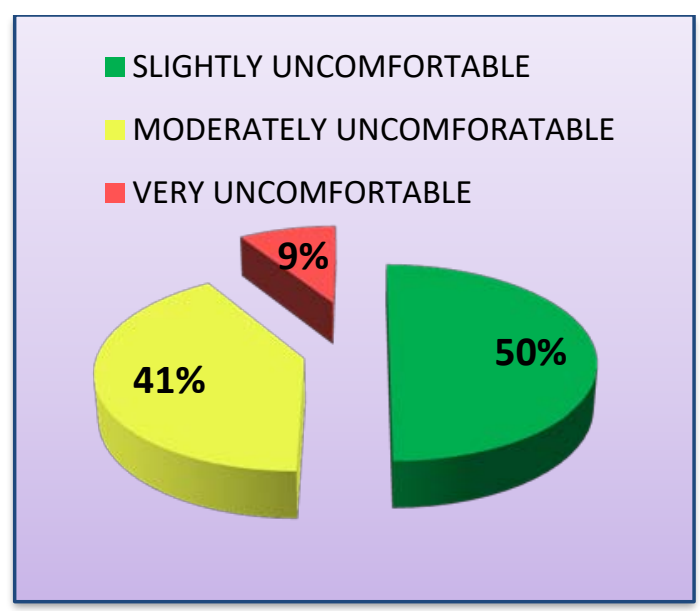

\section{DISCUSSION}

In this study, $65 \%$ population had neck pain as the most prevalent musculoskeletal dysfunction followed by low back pain (61\%). The neck and low back were the commonest areas of musculoskeletal dysfunction according to the analysis by Cornell musculoskeletal discomfort questionnaire.

The high prevalence of musculoskeletal dysfunction was probably due to maintaining the static posture for a prolonged period of time that is approximately for 18 to 20 hours of computer work per week. If accompanied by no stretching, movements or less number of breaks all these risk factors aggravate the pain in the neck region and low back. ${ }^{[15,16,17]}$ As the line of gravity passes anterior or posterior to the structures, it leads to abnormal weight bearing and this increases the weight of the load on soft tissues leading to strain and muscle imbalances leading to poor posture and thus the musculoskeletal dysfunction occurs. This may also lead to the postural cross syndrome and hence pain in the structures near the vertebral column arises. Prolonged sitting with a sustained posture of a neck (forward head posture) increases the risk of neck and shoulder pain associated with musculoskeletal symptoms. ${ }^{[17,18,21,24]}$

In postural angles; the only institute no. 2 had a lower viewing angle compared to normal range. Increase or decrease in the viewing angle may also cause the neck to be in flexion or extension instead of neutral neck alignment leads to pain in the neck region. ${ }^{[3][4][5]}$ Any increase or decrease in the viewing angle except in the normal range (15-30 degrees) for an extended period of time may cause acute musculoskeletal dysfunction. The line of gravity passes through the center of the body and determines the ideal posture. The line should pass through the vertebrae's leading to optimum weight bearing and less or no strain on soft tissues like ligaments, global and segmental core muscles supporting and stabilizing the spine (cervical vertebrae's). ${ }^{[22,23]}$ Along with the viewing angle, $65 \%$ of the students did not have adjustable monitors. Students had to be in a constant position of the neck during the working hours. This factor probably had contributed to the higher numbers of neck pain among students.

It was found that the elbow angle was lesser than the normal range in two computer science institutes (Institute 2 and 3) as there was an absence of forearm support, students were unable to position their elbows while using a keyboard or mouse. The absence of forearm support led to an increase in the severity of the neck and low back pain, as there is a reduced tendency to maintain the upright sitting posture. ${ }^{\text {[24- }}$ 29]

The hip angle was within the normal range for all the institutes also the mean seat height was in a normal range. The knee angle was reduced in three institutes as there was an absence of footrest and due to which students used to position their knees in lesser degrees compared to normal range.

The mean desk height and back support height of the chair were within the defined ranges that have explained that the both of these components of workstation were fairly maintained in all the four institutes. As the back support gives the proper alignment to the upper back hence the prevalence of upper back pain was comparatively less (35\%) among students. Contrary the low back pain was higher (61\%) due of faulty postures adapted by students; also as the work duration increases the tendency to maintain the upright sitting posture demolishes gradually and eventually, it leads to attaining slouch posture for a prolonged time. ${ }^{[30]}$

Only $26 \%$ of the students were aware of the proper ergonomics of a computer workstation and risk factors associated with poor ergonomics. This is an alarming sign that majority of the students were unaware about the ergonomics, proper alignment of body postures during work and the fitness program including stretching exercise program during break time to reduce the chances of various musculoskeletal dysfunctions. Most of the chairs were made of plastic, without lumbar/back support without freedom of flexibility, leading to assume a static posture of abnormal degrees in students for a prolonged period of time. Also, some heightened students had to adjust their body according to the chair and thus the efficacy of the workstation was highly reduced.

Students adopting healthy computing habits will have the better outcomes in the future. Various intervention programs for college students are necessary to reduce the chances of musculoskeletal dysfunction through computer use and its risk factors. ${ }^{[15,20]}$ The ergonomic interventions will not only create the awareness of proper ergonomics in students, but it will also encourage them for its prompt use. The institutes should consider the changing of fixed plastic chairs with chairs having proper forearm support and height adjustability; as this change may alone further decreases the prevalence of musculoskeletal dysfunction. The proper workstation analysis with appropriate ergonomic instructions to the computer science students is needed in every work set-up.

\section{CONCLUSION}

There was a high prevalence of neck pain and low back pain in computer science students. Neck pain was the most prevalent musculoskeletal dysfunction followed by the low back pain. Majority of the students were not aware of the 
proper ergonomics of the computer workstation. Prior establishment of work set-up the appropriate analysis of workstation and its characteristics is needed in all the computer science institutes. A further recommendation is required for conducting ergonomic lectures to the students that would explain them an appropriate ergonomics, proper alignment of body postures during work. In addition, students should also get an exposure for exercise programs through physiotherapy that would reduce the occurrence of musculoskeletal dysfunction in future.

\section{CONFLICT OF INTEREST}

No potential conflict of interest to this article was reported.

\section{VII.ACKNOWLEDGEMENT}

We would like to thank all the students participated in the study and the institutes for giving us an opportunity to conduct our study. We are thankful to our parents Dr. Sayed Irfan Ahmed (BUMS) and Mrs. Rehana Irfan Ahmed for their kind support and blessings throughout the journey. We are grateful to dedicate this work to them.

\section{REFERENCES}

[1] Cooper K, Sommerich C, Campbell-Kyureghyan. Computer usage and ergonomic risk factors among college students. IJSR, 2011; Vol 5(2).

[2] Rakhshaan Khan, Ambreen Surti et al. Knowledge and practice of ergonomics in computer users, Bahria University Medical and Dental College, Karachi, 2010.

[3] Armstrong TJ, Buckle P et al. A conceptual model for work related neck and upper limb musculoskeletal disorders. Scand F Work Environ Health 1993; 19: 73-84.

[4] A Checklist for Computer Workstations, Computer Ergonomics: Workstation Layout and Lighting, September 2004.

[5] Make Your Workstation Fit For You. Retrieved from Ergonomics Workstation Tool: http//internalapps.ergotron.com

[6] Berner, K., and Jacobs, K. The Gap between Exposure and Implementation of Computer Workstation Ergonomics in the Workplace. Work: A Journal of Prevention, Assessment, and Rehabilitation. 2002; Vol.19 (2): 193199.

[7] Wahlstrom J. Ergonomics, Musculoskeletal Disorders, and Computer Work. Occupational Medicine. 2005; Vol 55: 168-176. Retrieved from http://occmed.oxfordjournals.org/content/55/3/168.full.pdf 3 Ariens, G.A., Bongers,

[8] Douwes, M. et al. Are Neck Flexion, Neck Rotation, and Sitting at Work Risk Factors for Neck Pain? Results of a Prospective Cohort Study. Occupational Environmental Medicine, 2001; 58: 200-207. Retrieved from http://www.ncbi.nlm.nih.gov/pmc/articles/PMC1740110 4 Ergonomics. (2007).

[9] Safety and Health Topics. Occupational Safety and Health Administration. Retrieved from http://www.osha.gov/SLTC/ergonomics/5 Bernard, B.P. (July 1997). Musculoskeletal Disorders and Workplace Factors: A Critical Review of Workstation Analysis.

[10] Epidemiologic Evidence for Work-Related Musculoskeletal Disorders of the Neck, Upper Extremity, and Low Back. National Institute for Occupational Safety and Health. Retrieved from http://www.cdc.gov/niosh/docs/97-141/pdfs/97-141.pdf 6

[11] Cynthia R. The Importance of Ergonomics for the Safety Professional. EHS Today The Magazine for Environment, Health and Safety Leaders.2011; Retrieved from http://ehstoday.com/news/importance-ergonomics-safety3009/7.

[12] Ergonomics Programs: Preventing Musculoskeletal Disorders. (n.d). Occupational Safety and Health Administration. Retrieved from http://www.osha.gov/pls/oshaweb/owadisp.show_docume nt?p_table=UNIFIED_AGENDA\&p_id $=4108$

[13] Cornell Musculoskeletal Dysfunction Questionnaire. Cornell University, 2000.

[14] Norkins C. Joint goniometry. Chap 2. Measurement of angles, Lippincott publications, $4^{\text {th }}$ ed. 2000.

[15] Gerr, F., Marcus, M., Ortiz, D., White, B., Jones, W., Cohen, S., et al. Computer Users' Postures and Associations with Workstation Characteristics. American Industrial Hygiene Association Journal (2000, March) pp. 223-230.

[16] CAP: Workplace Ergonomics Reference Guide $2^{\text {nd }}$ Edition. A Publication of the Computer/Electronic Accommodations Program

[17] Jacobs $\mathrm{K}$ and Baker N.A.The association between children's computer use and musculoskeletal discomfort. Work, 2002; 18. 221-6.

[18] Royster L and Yearout R. A computer in every classroom - are schoolchildren at risk for repetitive stress injuries (RSIs)?, in Lee, G.C.H. (ed.) Advances in Occupational Ergonomics and Safety, 1999; (407-412). Amsterdam: IOS Press.

[19] Sommerich C and Korkmaz S. Exposure to ubiquitous mobile instructional technology in a high school setting: an observational study. In Proceedings of The Human Factors and Ergonomics Society 51st Annual Meeting. 2007 (479-483). Baltimore, MD: The Human Factors Society

[20] Alexander MW. An assessment of student computer ergonomic knowledge. Office Systems Research Journal, 1997; 15(2). 27

[21] Hupert N, Amick B, Fossel A, Coley C, Robertson M and Katz JN. Upper extremity musculoskeletal symptoms and functional impairment associated with computer use among college students. Work, 2004; 23. 85-93.

[22] Chang CH, Amick BC, Menendez CC, Katz JN, Johnson PW, Robertson M and Dennerlein JT. Daily computer usage correlated with undergraduate students' musculoskeletal symptoms. American Journal of Industrial Medicine, 2007; 50. 481-488.

[23] Noack-Cooper KL, Sommerich CM and Mirka G. College students and computers: Assessment of usage patterns and musculoskeletal discomfort. International Journal of Industrial Ergonomics. 2008.

[24] Menendez C, Amick B, Jenkins M, Janowitz I, Rempel D, Robertson M, Dennerlein J, Chang C and Katz JN. A multi-method study evaluating computing-related risk factors among college students. Work, 2007; 28. 287-297.

[25] Tullar J, Amick B, Robertson M, Fossel A, Coley C, Hupert N, Jenkins M and Katz JN. Direct observation of computer workplace risk factors of college students. Work, 2007; 28. 77-83.

[26] McAtamney L and Corlett EN. RULA: A survey method for the investigation of work-related upper limb disorders. Applied Ergonomics, 1993; 24(2). 91-99.

[27] Jenkins M, Menéndez CC, Amick IB, Tullar J, Hupert N, and Robertson MM. Undergraduate college students' upper extremity symptoms and functional limitations related to computer use: A replication study. Work, 2007; 28. 231-238.

[28] Brown R. Colleges \& Universities with Laptop or Notebook Computer Initiatives. Missouri: Westminster College. Retrieved Aug 18, 2008, from http://www2.westminster- 
mo.edu/wc_users/homepages/staff/brownr/NoteBookList.

html

[29] Cortés MC, Hollis C, Amick BC and Katz JN. An invisible disability: qualitative research on upper extremity disorders in a university community. J Occup Med, 2009; 18. 315-21.
[30] Szeto G P and Lee R. An ergonomic evaluation comparing desktop, notebook, and subnotebook computers. Archives of Physical Medicine and Rehabilitation, 2002; 83(4). 527-532. 